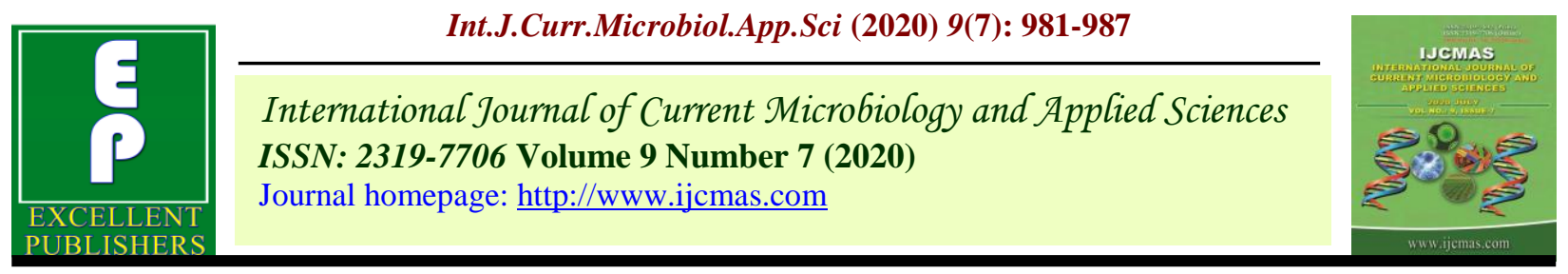

Original Research Article

https://doi.org/10.20546/ijcmas.2020.907.115

\title{
Analysis of Cold Storage Capacity Utilization with Specific Reference to a Farmers Market in Tamil Nadu, India
}

\author{
S. Moghana Lavanya*, K. Mahendran, S. Hemalatha and V. M. Indumathi \\ Department of Agricultural and Rural Management, Tamil Nadu Agricultural University, \\ Coimbatore-641041, India \\ *Corresponding author
}

\section{A B S T R A C T}

\begin{tabular}{l} 
Ke y w o r d s \\
Farmers Market, \\
Cold storage, \\
Capacity \\
Utilisation, \\
Arrivals, direct \\
marketing \\
\hline Article Info \\
$\begin{array}{l}\text { Accepted: } \\
11 \text { June } 2020 \\
\text { Available Online: } \\
\text { 10 July } 2020\end{array}$ \\
\hline
\end{tabular}

Agricultural supply chains are redundant with intermediaries and in price exploitation of farmers in marketing their produce. In order to help farmers realize better prices, direct marketing concept such as Uzahavar sandhai in Tamil Nadu, Rythu Bazar in AP etc were initiated. The study was undertaken to know the usage of cold storage units in the farmers market located in Anna Nagar, Madurai of Tamil Nadu. The secondary information regarding the arrivals, number of farmers and number of consumers participated, usage of cold storage facility were collected for the past five years and same was analyzed and presented. The results indicated that capacity utilization of the cold storage unit available was low and sufficient interventions are needed for promoting better usage.

\section{Introduction}

Agricultural supply chains are redundant with intermediaries and in price exploitation of farmers in marketing their produce. As a means to reduce the exploitation and ensure a better share of consumers price to the farmer producers, the concept of direct marketing was introduced. The direct marketing initiative focusses on the direct interaction of farmers and the consumers surpassing the role of middlemen and the market commission agents. Farmers' Market had its conception in Kal Ghoj in Russia. The Government of Tamil Nadu introduced the Scheme of Farmers Market (Uzhavar Santhai) in the year
1999. Similar type of direct marketing initiatives are also being adopted in other states under different names viz., Apni Mandis / Kisan Mandis in Punjab, Rythu Bazars in Andhra Pradesh.

The First Farmers Market in Tamil Nadu was established in Anna Nagar, Madurai in the year 1999. Understanding the effectiveness of the initiative, the Government expanded the number of such markets to currently 179 located across the state in urban and semiurban areas. It's a synergistic relationship for both farmers and consumers as the farmer gets $15 \%$ more price and the later pays $20 \%$ less for the produce as compared against open 
market prices. Farmers Market in Tamil Nadu is a beneficial initiative that had stood many challenges over twenty years of time frame. The intentions that instigated for the establishment of the scheme were;

To establish direct contact between farmers and consumers.

To eliminate middlemen.

To provide fresh produce at affordable cost. To provide higher prices for produce than the wholesale price.

To serve as a technical information Centre and Training Centre to the farmers.
Consequently, the farmers market has helped the farmers grow their socio-economic status over the years. It strives at providing fresh produce grown by the local farmers at a reasonable cost for the consumers and in realization of better profit.

The Farmers Market are operated under the administrative control of the District Market Committees established by the Department of Agricultural Marketing and Agribusiness, Government of Tamil Nadu. The details of existing Farmers markets in various districts of Tamil Nadu state is given in table-1.

Table.1 Existing Farmers Markets in Various Districts of Tamil Nadu state

\begin{tabular}{|c|c|c|}
\hline S.No & District & No of Farmers Market \\
\hline 1 & Ariyalur & 2 \\
\hline 2 & Coimbatore & 9 \\
\hline 3 & Cuddalore & 5 \\
\hline 4 & Dharmapuri & 5 \\
\hline 5 & Dindigul & 5 \\
\hline 6 & Erode & 5 \\
\hline 7 & Kancheepuram & 14 \\
\hline 8 & Kanniyakumari & 2 \\
\hline 9 & Karur & 5 \\
\hline 10 & Krishnagiri & 5 \\
\hline 11 & Madurai & 7 \\
\hline 12 & Nagapattinam & 3 \\
\hline 13 & Namakkal & 6 \\
\hline 14 & Nilgiris & 4 \\
\hline 15 & Perambalur & 2 \\
\hline 16 & Pudukkottai & 6 \\
\hline 17 & Ramanathapuram & 3 \\
\hline 18 & Salem & 11 \\
\hline 19 & Sivagangai & 4 \\
\hline 20 & Thanjavur & 5 \\
\hline 21 & Theni & 7 \\
\hline 22 & Tirunelveli & 6 \\
\hline 23 & Tiruppur & 5 \\
\hline 24 & Tiruvallur & 6 \\
\hline 25 & Tiruvannamalai & 8 \\
\hline 26 & Tiruvarur & 7 \\
\hline 27 & Tiruchirapalli & 7 \\
\hline 28 & Thoothukudi & 2 \\
\hline 29 & Vellore & 9 \\
\hline 30 & Villupuram & 6 \\
\hline 31 & Virudhunagar & 8 \\
\hline & Total & 179 \\
\hline
\end{tabular}

(Source: GoTN, 2019) 
The activities in Farmers market have been continuously revisited by the government agencies since inception for further improvements in terms of making their operations more effective and in addressing the various problems faced by the farmers and consumers over time. One of the important aspects in the evolution of farmers market to its current status has been the improvements in the infrastructure facilities within the markets especially the installation of cold storage infrastructure facilities for storage of unsold fruits and vegetables by the farmers. This helped the farmers in overcoming the loss of revenue in terms of ensuring less wastages and avoiding low prices that usually exists during the fag end of the day. For the consumer it helped them to have a continuous supply of good quality vegetables at reasonable prices.

\section{Cold storages}

Cold Storages are the buzz of present agricultural revolution aiming at curbing postharvest losses that occurs at every part of the supply chain. Evidently, the fruits and other consumables can be stored at low temperature that evades any microbial infections that may lead to decaying of the produce. India is one of the largest producers of fruits and vegetables, of which almost $30 \%$ goes to the dump as waste. The Government has explored an array of benefits it offers and has sanctioned for establishment of cold storages in every farmers market. This would help the farmers to store their produce at the storage and market it after a couple of days while maintaining the freshness.

The availability of cold storages in the farmers market helped them to stock their produce that might otherwise be deemed as unfit for sale. In effect there are various schemes and subsidies available at national and state level encouraging entrepreneurs to take up business in the cold chain sector.

This has dramatically reduced the wastage of fruits and vegetables. Tamil Nadu government has set up 27 cold storage units in various farmers markets to encourage farmers to store the unsold produce for reducing the waste. The list of cold storage units in the Farmers market is as given in table-2.

Panchanathan et al., (2008) have concluded in their study of consumers preference and satisfaction in Uzhavar Sandhai at Namakkal District that it is beneficial to small and marginal farmers who can bring limited quantity of produces, which they cannot sell in the wholesale markets. Jyothi (2014) briefed about the efficient agricultural marketing and sustainable development that become efficient with better agricultural marketing which would generate economy wide gains in output and wages, raises agricultural producer prices, reduces consumer food price, and increases private consumption, particularly by low-income households. Devkota et al., (2014) conducted a study regarding the losses of harvested horticultural produces in the major fruit and vegetable wholesale markets of Nepal to identify the major causes of fruits and vegetable wastage. Their results stated that unavailability of chemical fertilizers in right time and amount is one of the major hindrances for the development of agriculture industry in Nepal and hence the farmers were facing the problem of lower yields than recommended.

Balachandran (2019) had carried out a study on "Marketing Management of Specialty Products via Uzhavar Santhais by Farmers Hub". He concluded that with support from the government and simple Supply Chain establishment better marketing and Sales technique can help both farmers and consumers even society to a great extent. He also stated that more importance needs to be given to the retailing of the perishable farm 
produce in order to avoid distress among farmers and to create a Healthy society. From a study by Puneeta and Agrawal (2012), it could be concluded that vegetable market waste or domestic organic waste can be recycled at consumer (home)level by amending with sand-soil and waste paper shredding in container or tank units.

Dessalegn et al., (2016) reported that that, fruit trading is mainly handled by young and relatively educated individuals compared to fruit producers. However, their experience on fruit marketing is very limited and resulted in inappropriate postharvest handling.

Arivazhagan et al., (2012) concluded many reasons for food waste and loss, out of which, lack of cold storage was considered as primary reason for maximum wastage. More number of distribution channels were creating problem of more damage and price increase. Third major reason was unsold wastage.

Shukla and Rai (2014) studied the behaviour of market arrivals and prices of onion, garlic and turmeric in selected markets of U.P. state. The study has confirmed the negative relationship between market arrivals prices of onion, garlic and turmeric over the years in all two markets.

Salim et al., (2008) have found out that the direct contact with the consumers had enhanced income of the farmers. Like any other industry, diversification of products i.e. selling more than two products has resulted in high average sales per day. The Uzhavar Sandhais in general, has done a laudable job in making the marketing easy for the farmers.

Rathinam (2015) had concluded from his research that local administration should also enlighten the farmers to acquaint themselves with the latest marketing strategies and help them become efficient and self-sufficient farmers. Also, the farmers should be trained to preserve their product sto keep it fresh. Hybrid varieties introduced will increase the productivity.

\section{Materials and Methods}

The study was undertaken to know the usage of cold storage units in the farmers market located in Anna Nagar, Madurai. The secondary information regarding the arrivals, number of farmers and number of consumers participated, usage of cold storage facility were collected for the past five years and same was analyzed and presented.

\section{Results and Discussion}

Madurai Anna Nagar Farmers market was the first one to be started in Tamil Nadu state during the year 1999. The market is located in an area of 1.25 acres with 130 shops and 270 registered farmers. Farmers producing fruits and vegetables from twelve villages are participants in this market. The details of arrivals, number of participants and traded value of vegetables are presented in Table 3.

It could be understood from the above table that the number of farmers participating in thee market activities has continuously declined from 42413 in 2012-13 to 30303 in 2016-17. Consequently, the market arrivals of fruits and vegetables have also declined from 15744 tonnes to 11919 tonnes during the same period. The decline was noticed in the number of participating consumers as well as the value of traded fruits and vegetables. The average per day arrivals decreased from 43.10 tonnes to 32.70 tonnes. This may be due to the establishment of another central market nearby resulting in the overall performance of the Anna Nagar Farmers declining. Though there is overall decline in other measures, the value of vegetables traded has not declined may be due to the fact of general price increase and improvement in the quality of 
the vegetables offered for sale in this market. The cold storage facility was established with $2 \mathrm{mt}$ capacity in the year 2009 and the utilization details are presented in Table 4.

The share of quantity of vegetables stored in cold storage to total arrival indicates a meagre range of $0.51 \%$ to $0.99 \%$ during the years 2012-2017. The results also indicated that about $13 \%-16 \%$ of the participating farmers have utilized the cold storage facility available in the Farmers Market. The details of average quantity of fruits and vegetables stored by the farmers and the average value of storage are presented in the table-5.

It could be seen from the above table that the average quantities of stored fruits and vegetables have increased over the years though the number of farmers participating in cold storage has decreased. The corresponding value of cold stored fruits and vegetables has also shown sharp increase indicating higher value storage over the five year period under study.

Table.2 List of Farmers Market with Cold Storage Facilities in Tamil Nadu State

\begin{tabular}{|c|c|c|c|}
\hline S.No & Place & S.No & Place \\
\hline 1 & Attur & 15 & Namakkal \\
\hline 2 & Ammapattai & 16 & Nanganallur \\
\hline 3 & R.S.Puram, Coimbatore & 17 & Palayamkottai \\
\hline 4 & K.K.Nagar, Trichy & 18 & Rasipuram \\
\hline 5 & Asthampatti, Salem & 19 & Singanallur, Coimbatore \\
\hline 6 & Chokkikulam, Madurai & 20 & Sooramangalam, Salem \\
\hline 7 & Cuddalore & 21 & Thathagapatti, Salem \\
\hline 8 & Cumbam & 22 & Theni, \\
\hline 9 & Gudiyatham & 23 & Thoothukudi \\
\hline 10 & Hosur & 24 & Tiruppur (North) \\
\hline 11 & Karur & 25 & Trichy Anna Nagar \\
\hline 12 & Kumbakkonam & 26 & Vadaseri. Kanniyakumari \\
\hline 13 & Anna Nagar, Madurai & 27 & Vaniyambadi \\
\hline 14 & Mannargudi & & \\
\hline
\end{tabular}

(Source; GoTN, 2018)

Table.3 Market Arrivals of Fruits and Vegetables - Madurai Anna Nagar Farmers Market

\begin{tabular}{|c|c|c|c|c|c|c|}
\hline Year & $\begin{array}{c}\text { Farmers } \\
\text { (Nos) }\end{array}$ & $\begin{array}{c}\text { Arrivals } \\
\text { (Tonnes) }\end{array}$ & $\begin{array}{c}\text { Value } \\
\text { (Rs. lakhs) }\end{array}$ & $\begin{array}{c}\text { Consumers } \\
\text { (in lakhs) }\end{array}$ & $\begin{array}{c}\text { Average Per } \\
\text { Day Arrival } \\
\text { (Tonnes) }\end{array}$ & $\begin{array}{c}\text { Average } \\
\text { Value } \\
\text { Rs/Kg }\end{array}$ \\
\hline $\mathbf{2 0 1 2 - 2 0 1 3}$ & 42413 & 15744 & 357.82 & 26.23 & 43.10 & 22.73 \\
\hline $\mathbf{2 0 1 3 - 2 0 1 4}$ & 40567 & 14208 & 404.03 & 41.76 & 38.90 & 28.44 \\
\hline $\mathbf{2 0 1 4 - 2 0 1 5}$ & 38363 & 14448 & 376.92 & 23.96 & 39.60 & 26.09 \\
\hline $\mathbf{2 0 1 5 - 2 0 1 6}$ & 33985 & 13844 & 381.25 & 22.33 & 37.90 & 27.54 \\
\hline $\mathbf{2 0 1 6 - 2 0 1 7}$ & 30303 & 11919 & 332.62 & 19.78 & 32.70 & 27.91 \\
\hline
\end{tabular}


Table.4 Farmers Participation in Cold Storage Utilization- Madurai Anna Nagar Farmers Market

\begin{tabular}{|c|c|c|c|c|c|c|}
\hline Year & $\begin{array}{c}\text { Participatin } \\
\text { g Farmers } \\
\text { (Nos) }\end{array}$ & $\begin{array}{c}\text { Farmers } \\
\text { Utilized Cold } \\
\text { Storage (Nos) }\end{array}$ & $\begin{array}{c}\text { Average } \\
\text { Utilization } \\
(\mathbf{\%})\end{array}$ & $\begin{array}{c}\text { Arrivals } \\
\text { (MT) }\end{array}$ & $\begin{array}{c}\text { Quantity of } \\
\text { Vegetables } \\
\text { Stored (Kgs) }\end{array}$ & $\begin{array}{c}\text { Share of } \\
\text { Quantity } \\
\text { Stored (\%) }\end{array}$ \\
\hline $\mathbf{2 0 1 2 - 1 3}$ & 42413 & 5440 & 12.83 & 15744 & 107225 & 0.68 \\
\hline $\mathbf{2 0 1 3 - 1 4}$ & 40567 & 6539 & 16.12 & 14208 & 72545 & 0.51 \\
\hline $\mathbf{2 0 1 4 - 1 5}$ & 38363 & 6280 & 16.37 & 14448 & 116120 & 0.80 \\
\hline $\mathbf{2 0 1 5 - 1 6}$ & 33985 & 4483 & 13.19 & 13844 & 90960 & 0.66 \\
\hline $\mathbf{2 0 1 6 - 1 7}$ & 30303 & 4121 & 13.60 & 11919 & 117845 & 0.99 \\
\hline
\end{tabular}

Table.5 Quantity and Value of Vegetables Stored - Madurai Anna Nagar Farmers Market

\begin{tabular}{|c|c|c|c|c|c|}
\hline Year & $\begin{array}{c}\text { Farmers } \\
\text { (Nos.) }\end{array}$ & $\begin{array}{c}\text { Quantity of } \\
\text { Vegetables } \\
\text { Stored (Kgs) }\end{array}$ & $\begin{array}{c}\text { Value of } \\
\text { Vegetables } \\
\text { Stored } \\
\text { (Rs.) }\end{array}$ & $\begin{array}{c}\text { Average Quantity } \\
\text { of Vegetables } \\
\text { Stored/Farmer } \\
\text { (Kgs) }\end{array}$ & $\begin{array}{c}\text { Average Value of } \\
\text { Vegetables } \\
\text { Stored/Farmer } \\
\text { (Rs) }\end{array}$ \\
\hline $\mathbf{2 0 1 2 - 2 0 1 3}$ & 5440 & 107225 & 2315850 & 19.71 & 425.71 \\
\hline $\mathbf{2 0 1 3 - 2 0 1 4}$ & 6539 & 72545 & 1781190 & 11.10 & 272.39 \\
\hline $\mathbf{2 0 1 4 - 2 0 1 5}$ & 6280 & 116120 & 3559490 & 18.49 & 566.80 \\
\hline $\mathbf{2 0 1 5 - 2 0 1 6}$ & 4483 & 90960 & 1980490 & 20.29 & 441.78 \\
\hline $\mathbf{2 0 1 6 - 2 0 1 7}$ & 4121 & 117845 & 2825440 & 28.59 & 685.62 \\
\hline
\end{tabular}

The number of farmers participating in Madurai Anna Nagar Farmers Market has declined and the fruits and vegetable arrivals as well as sales have also declined during the five years of study. The capacity utilization of the cold storage unit available was also found to be only around $13 \%$ in contradiction to the fact that there was an increase in the quantity stored per farmer in the cold storage and correspondingly the value of storage.

A detailed primary level study to understand the perception of the participating farmers as well as the consumers would throw better light for not only improving the utilization of Cold storage in the market but also to improve the arrivals and consumer footfalls to achieve the objectives set forth in establishment of Farmers Markets by the Government.

\section{References}

Arivazhagan, P. Geetha, and Ravilochanan Parthasarathy. (2012). Analysis of Sources of Fruit Wastages in Retail outlets inChennai, Tamilnadu, India. International Journal of Trade, Economics and Finance, Vol. 3, No. 3, June 2012

Devkota, A. R., D.D. Dhakal, D.M Gautamand J.P. Dutta. (2014). Assessment of fruit and vegetable losses at major wholesale markets in Nepal. International Journal of Applied Sciences and Biotechnology, Vol 2(4): 559-562

DOI: 10.3126/ijasbt.v2i4.11551

Diwaker Nath Shukla and Raj. J., (2014).An economic study of behaviour of marketarrivals and prices of onion, garlic and turmericin selected markets of U.P.International Research Journal 
of Agricultural Economics and Statistics, Volume 5, Issue 2, September, 2014

Jayakumar Balachandran. (2019). Marketing Management of Specialty Products via UzhavarSanthais by Farmers Hub. International Journal of Scientific Research and Review. Volume 8, Issue 1,2019

Jyothi, K.C. (2014). Agricultural Marketing and Sustainable Development. IOSR Journal of Economics and Finance (IOSR-JEF), Volume 4, Issue 2. (MayJun. 2014)

Panchanathan, N. , S. Senthilkumar, R. Mathivannan. (2008). A Study on Consumer Preference and Satisfaction in Uzhavar Sandai at Namakkal District. Indian Journal of Marketing, Volume 38, Issue 2, February 2008

Puneeta Dandotiya and O. P. Agrawal., (2012). Stabilization of vegetable market waste through vermicomposting.
International Journal of Science and Research (IJSR). Volume 3 Issue 6, June 2014

Rathinam, P. 2015. Consumer Satisfaction towards R.S.Puram Uzhavar Sandhai, Coimbatore. European Journal of Commerce and Management Research [EJCMR], Special Issue 1, 2015

Salim, M.H., Hari Sundar.G, Anoop Das. (2008). 'Uzhavar Sandhais - A Boon or Bane for Rural Empowerment in Tamil Nadu'. Marketing to Rural Consumers Understanding and tapping the rural market potential, 3, 4, 5 April 2008

Yigzaw Dessalegn, Habtemariam Assefa, Teshome Dersoand Amare Haileslassie. (2016). Assessment of fruit postharvest handling practices andlosses in Bahir Dar, Ethiopia. African Journal of AgriculturalResearch, Vol. 11(52), pp. 5209-5214, 29 December, 2016. DOI: 10.5897/AJAR2016.11731.

\section{How to cite this article:}

Moghana Lavanya. S., K. Mahendran, S. Hemalatha and Indumathi. V. M. 2020. Analysis of Cold Storage Capacity Utilization with Specific Reference to a Farmers Market in Tamil Nadu, India. Int.J.Curr.Microbiol.App.Sci. 9(07): 981-987. doi: https://doi.org/10.20546/ijcmas.2020.907.115 